Available online at http://dergipark.gov.tr/iujad

Inonu University Journal of Art and Design

Faculty Homepage: http://www.inonu.edu.tr/tr/gsf

\title{
DİSİPLİNLER ARASI ETKİLEŞİM: MÜZE BAĞLAMINDA ADLİ SANAT VE YENİDEN YÜZLENDİRME
}

\section{MULTIDICIPLINARY INTERACTION:FORENSIC ART AND FACIAL RECONSTRUCTION AS PART OF MUSEUMS}

\section{Aysun ALTUNÖza,*}

a Ankara Hacı Bayram Veli Üniversitesi Güzel Sanatlar Fakültesi, Ankara, Türkiye

Article history: Received 01-12-2019 / Accepted 01-31-2019

\section{ÖZT ABSTRACT}

Bilindiği gibi yeniden yüzlendirme adlibilimleri ilgilendiren durum tespit ve kimlik çalışmaları ile yeniden inşayı kapsamaktadır. Adlisanat da diğer disiplinler gib adlibilimler çatısı altında ortak amaç doğrultusunda çalışmaktadır. Ülkemizde henüz literatürde etkin yer olmayan adlisanatın, müze ve adlibilimlere sağlayacağ katkıların vurgulandığı bu makalede asıl amaç; disiplinlerarası koordinasyonu gerekli kılan yeniden yüzlendirme çalışmasının lisansüstü eğitim programlar kapsamında ele alınmasının gereğini vurgulamaktır. Böylelikle adlisanat alanında uzman ve deneyimli meslek adamlarının yetişmesi ve disiplinlerarası çalışma gruplarında aktif görevler alarak daha kaliteli çalışmaların müze ve adli birimlerce değerlendirilmesine öncülük edeceği düşünülmektedir.

Anahtar Kelimeler: Adli Bilim, Adli Sanat,

Disiplinlerarası, Yeniden Yüzlendirme, Müze
As in the case of the unknown, the facial re-construction includes the identification and the re-construction of forensic sciences. Just like the other disciplines forensic art, works for common purposes under the roof of forensic sciences too. In our country, it has been emphasized that forensic art, which has not a place in the literature, can present our museum and forensic knowledge to emphasize the necessity of addressing the post-graduate education programs of the resettlement work, which requires interdisciplinary coordination. In this way, it is thought that the professionals in the field of forensic art will be educated and active services will be taken in interdisciplinary working groups.

Keywords: Forensic Science, Forensic Art,

Multidisiplinary, Facial re-Construction, Museum

\section{GİRIŞ}

İçinde bulunduğumuz post-tekno dönem tinsel vücudu köreltirken diğer yandan -miş gibilerle avunmamızı salık vermekte. Sanatta yapay görüntüler her ne kadar gerçek görüntüden alınan hazzı yaşatsa da bilimde yapay görüntü ile biçimin geri dönüşü, ruhun ölümsüzlüğünü ne kadar gerçek kılabilecektir. Bu makalede asıl amaç simülatif görüntüye ruh vermek değildir. Görünenden haz almak da değil. Amaç bilim ve sanatın kendi disiplinlerinden destekle oluşturdukları ortak çalışma alanına dikkat çekmek ve alt çalışma gruplarına vurgu yapmaktır.

Diğer taraftan her iki disiplinin oluşturduğu ortak-melez disiplinlerin müze ve müze eğitimindeki yeri ve gereğine özellikle değinmek bu noktada da yetiştirilecek alan uzmanlarının gerekliliğine dikkat çekmek gerekmektedir. Bu amaçla lisansüstü tez çalışmasına konu edilen bir kafatası üzerinden yapılan yeniden yüzlendirme ile literatüre yeni bir örnek de kazandırılmıştır.

\section{Bilim ve Sanatın Kesişme Noktası: Adli-Sanat}

Adli-Sanat'ın ne olduğuna ilişkin varılması beklenen yargı cümlesi, sanatın ve bilimin kesişme noktası olmalıdır. Bu sanat/bilim ilişkisinin, adli bilimin bilgi ve bilimsel prensiplerini, sözlü ifadelerin yanı sıra görsel bir biçimde kullanabilme ihtiyacından ortaya çıktığı söylenebilir. Günümüzde Adli bilim, adli olay mağdurlarının fiziksel betimlemelerinin güçlü ifadesine gerek duyduğu noktada, adli sanat alanı ile ortaklaşa çalışmaktadır. Taylor (2001:3)'a göre adli sanat:

Suçluların tespiti, cinayet mağdurlarının ya da oluş şekli ve süreci bilinen ölümlü vakaların tanımlanması, olayın çözümlenmesi ile kimliği belirlenemeyen kurbanların kimliklendirilmesine 
yardımcı olan sanat koludur...Adli Sanat doğası gereği çoklu ortamdır, öncelikli amacı görsel bilgi sunmaktır.

Ülkemizde henüz yaygın bilinen bir meslek grubu olamamış adli sanat, birçok gelişmiş ülkede adli kurumların çalışma alanı içinde varlık göstermektedir. Küreselleşmenin bir getirisi olarak sanatın disiplinleri, vizyon ve misyon bağlamında değişikliğe uğramış, diğer sanat ve bilim dalları ile etkileşerek teknik ve amaç alışverişinde bulunmuştur. İki ve üç boyutlu çalışmalarıyla adli bilimin içinde yer alan adli sanat, alanına yeni açılımlar kazandırırken diğer bilim dallarına da katkı sağlamaktadır. Adli bir durum olsun ya da olmasın bu kategoride sanat, heykel sanatı ve antropoloji ile sessiz işbirliğini sürdüren bilim-sanat alanı halini almıştır.

Bir olayın adli olması cinayet olgusu ile kabaca tanımlanabilmektedir. Dönemlerine bağlı olarak doğal sürecinde ölen ya da öldürülen kişilerin iskeletleri-kemikleri üzerinde araştırma yapan antropolog ile paleo-antropologların kendi içlerinde çalışma sınırları tanımlanmış olmasına karşın bu literatürde sanat dalları (resim, heykel), ana hatlarıyla adli-sanat başlığı altında toplanmıştır. Adli-sanat alanında varlık gösteren adli-heykeltraşlar ise teknik ve materyal bağlamda üç boyutlu çalışmalarıyla, konuyla ilişkili tüm alanlara destek vermektedir. Gatlift, ilk üç boyutlu yeniden yüzlendirme deneyimine ilişkin yazısında, adli-heykeltıraşın adli-bilim alanındaki önemine Krogman'ın şu sözleriyle değinir:

Ortalama bir kimlik saptama uzmanı sanatın bilimi tamamlaması gereği noktasında, tek başına yeterli ve yetenekli olamayabilir. Adli bilimin dataları ve yönlendirmeleri doğrultusunda verileri sağlıklı ve gereği gibi kullanan heykeltıraş, benim ihtiyacımı ve eksiğimi tamamlar (Taylor, 2001:420).

1940'lı yıllarda adli vakaların kimliklerinin tespitleri için kullanılan yeniden yüzlendirme teknikleri, 20. yy. başlarında müzelerde yer alan tarih öncesi iskeletlere ait kafatasları üzerinde yeniden inşaa amaçlı kullanılmıştır. Yeniden yüzlendirme çalışmaları ülkemizde 1900 'lü yılların sonlarında başlatılmıştır. Dünyada ekip çalışmasıyla ortaya çıkarılan başarılı yüzlendirmelerin başında kral Tutankhamun, kraliçe Nefertiti, gök bilimcisi Nicolaus Copernicus J. Sebastıan Bach, Emmanuel Kant gibi yakın tarih örneklerinin yanı sıra tarih öncesine ait Ötzi ve Lucy yüzlendirmeleri de gelir. Ancak tarih ve kültür beşiği ülkemizde yüzlendirmesi yapılmış bu tür örneklere pek rastlanmaz. Anadolu Medeniyetleri Müzesinde yer alan "Kral Midas'ın yüzlendirmesi, Bodrum Sualtı Arkeoloji Müzesinde yer alan "Kayra Prensesi'nin yüzlendirmesi kadar üzerinde konuşulması gereken özellikli bir örnektir.

Görülüyor ki bu ortak çalışmada antropolog ve Adli-paleoantropologların dataları doğrultusunda, kimliği belirsiz iskelet ya da kafatası, adli-heykeltıraşlar tarafından yeniden inşa edilerek kimliklendirilmektedir. Böylece Adli-sanat bir yandan karanlık ve şüpheli adli olgulara açıklık getirirken, diğer taraftan da tarihi önemi olan antropolojik ve paleoantropolojik bulguların müzelerde gerçek görünümleri ile sergilenmesine katkıda bulunulur. Adli sanat alanı içinde önemli bir yer alan yeniden yüzlendirme-kimliklendirme "modern zamanların çalışmalarına farkıı boyut ve anlam katmaktadır. İlk çağ insanının tahmini görüntüsünü elde etmek amacı ile arkeologların girişimlerine yardımcı olmak için yüz konstrüksiyonları (yapılandırmaları-yüzlendirmeleri) yapılmaktadır" (2007;76) (URL-1,2019).

Kazılarda elde edilen iskeletlerin yaş, cinsiyet, ölüm şekilleri ve nedenleri ile hangi döneme ait oldukları gibi birçok verinin derlenmesi noktasında çalışmalar yürüten antropologlar ile adlipaleo-antropologların adli bilimler ve müze çatısı altında adli-heykeltıraşlarla koordineli çalışmaları, birçok güncel örnekle sabitlenmiştir. Ülkemizde de bulunan bu örnekler literatürde önemli yer almaktadır.

Manchester Üniversitesi Tıp Fakültesi Anatomi ABD'de görev yapan Richard Neave, mucizeler yaratan tıbbı illüstratör olarak bilinmektedir. Dünyada ve ülkemizde de bulunan birçok tarihi öneme sahip kişiliklerin kafataslarını yeniden yüzlendiren Neave, uygulamalarında Rus Gerasimov'un izini takip ettiği bilinir. Ayrıcalıklı olana çalışmaları; Alman şair ve oyun yazarı Schiller, İtalyan Rönesans ressamı Raphael ve korkunç İvan'ın kafataslarının yüzlendirmeleri 
ile büyük İskenderin babası II. Phillip ve ülkemizde bulunan ve sergilenen Kral Midas'ın yüzlendirmeleri olarak sıralanabilir. Bu çalışmalardan II. Phillip'in yaralanmış hali ile tedavi sonrası yüzünün görüntülerine ait yüzlendirmeleri alana önemli katkı sağlamıştır. Ülkemiz için de önem içeren diğer çalışması ise Kral Midas'ın yüzlendirmesidir. Neave, Manchester'daki meslektaşı John Prag ile işbirliği içinde Kral Midas'ın yüzlendirmesini gerçekleştirmiştir. Bilindiği üzere Sakarya ovasının en büyük Tümülüs'ü olan Midas Höyüğündeki kazı araştırmaları sırasında ahşaptan inşa edilmiş mezar odasında, 60-65 yaşlarında, 1.59 metre boyunda bir erkek bedenine rastlanmıştır. Yatakta yatar pozisyonda korunmuş iskeletin etrafında 350 adet bronz kap, süs eşyaları, metalden üç ayak-sac ayağı, çeşitli ahşap eşya ve çömlekler bulunmuştur. Mezar Prof. Dr. Radney Yong'a göre "42 yıl hüküm süren Frigya'nın en önemli kralı olan Midas'a aittir. Kralın saltanatı barbar bir ırkın (Cimmerian) istilası sırasında şehrin yok edilmesiyle son bulmuş ve Kral öldürülmüştür. Bazı kaynaklara göre de Kral, boğa kanı içerek intihar etmiştir" (A.J.N.V. Prag, 1989:159) (URL-2,2019). Kafatası (Resim1) üzerinde yapılan adli araştırmalarda Kralın kulaklarına ait söylentilere dair herhangi bir kanıta rastlanmamıştır. Manchester Üniversitesi'nden Genetik bilimci Dr Roger Wood, "kulağın dış veya üst kenarlarında aşırı tüylenmeyle ilişkilendirilebilecek 'tüylü pinna' olarak bilinen genetik bozukluğun neden olma olasılığını" ortaya atarak söylentilere bir anlamda açıklık getirmiştir (https://www.rn-ds-partnership.com/reconstruction/midas.html), (URL-3, 2019).

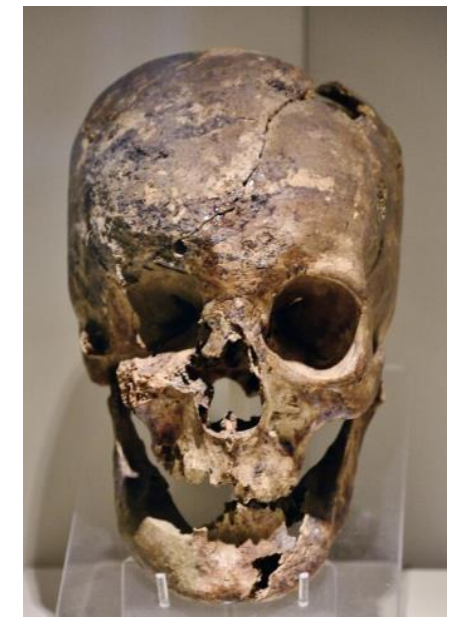

Resim 1: Kral Midas'a ait kafatası, (URL-4, 2019)

Ülkemizde Ankara Anadolu Medeniyetleri Müzesinde özel eşyaları ile korunan ve sergilenen Kral Midas'ın yüzlendirmesi, İstanbul Üniversitesinden Dr. Veli Sevin, Ankara Üniversitesi Paleontoloji bölümünden Prof. Dr E. Bostancı ile Prof. Dr. B. Alpagut aracılığıla Neave ve Prag'ın koordineli çalışmaları sonucu gerçekleştirilmiştir (Resim,2).

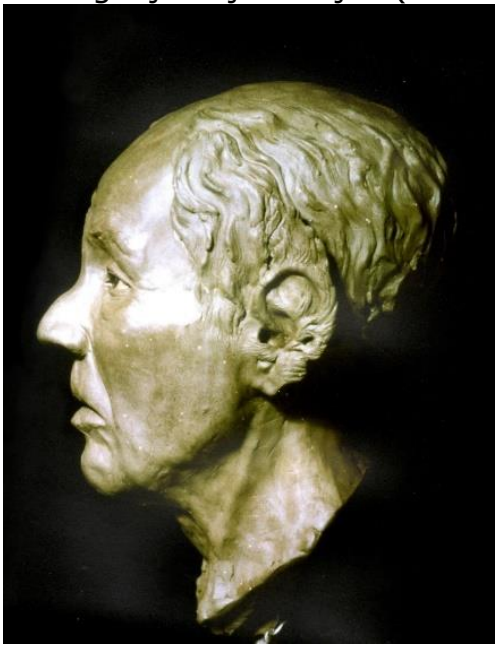


Resim 2: Karal Midas Yüzlendirmesi (URL-5, 2019)

\section{Müze ve Ötzi Yüzlendirmesi}

Tahmini 46 yaşında sol omzuna denk gelen bir delici aletin (ok) açtığı yaranın kan kaybına neden olmasından kaynaklı öldüğü düşünülen Buz Adam Ötzi (Resim, 3) bu koordinasyona önemli ve güncel bir örnektir. 1991 yılında, iki dağcı çift tarafından, kıyafetleri ve ekipmanlarıyla birlikte, İtalya'nın Ötztal Vadisi Alpleri'nde (Schnalstal / ValSenales Vadisi buzulu) şans eseri keşfedilen Ötzi'nin yüzlendirmesini Hollandalı heykeltıraş Adrie ve Alfons Kennis ikiz kardeşler yapmıştır. Bu gün Güney Tirol Arkeoloji Müzesinde kendisine ait özel bir bölmede iskeleti sergilenen Ötzi'nin, Kennis kardeşler tarafından yapılan yüzlendirme ve etlendirmesi de yine aynı müzede sergilenmektedir.

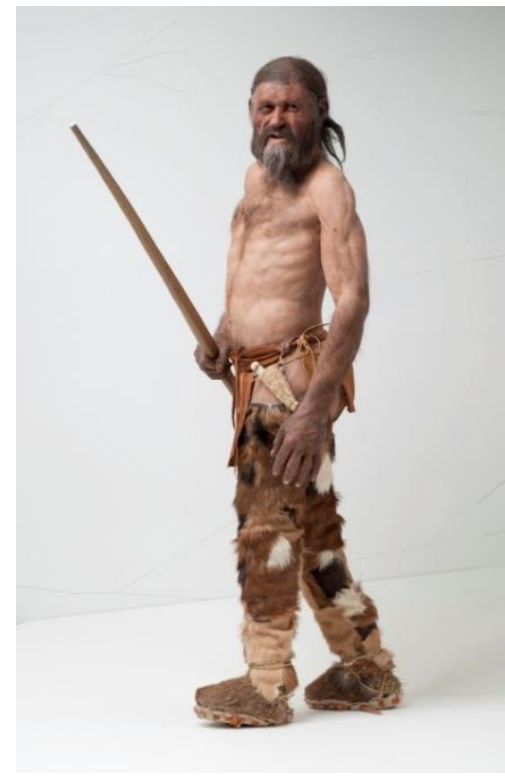

1. Resim3: Buz Adam Ötzi, (URL-6, 2018)

Silikon kauçuk, sentetik reçine, renkli pigmentler ve gerçek saçlar kullanılarak gerçek görüntüsüne en yakın betimlemesiyle Ötzi, olağanüstü koşullar sayesinde günümüze kadar korunmuş olan Bakır Çağı'ndan bir buzul mumyasıdır. Avusturya ve İtalya sınırında deniz seviyesinden $3210 \mathrm{~m}$ yükseklikte buzullar içinde bulunan iskelet çevresinde yapılan araştırmada, üzerinde koyun derisi ve sığır postundan yapılmış bir giysi ile avlanmada kullandığı baltasının olduğu tespit edilmiştir. Buzulda kaldığı sürenin uzunluğuna bağlı olarak, vücut sıvısının çoğunun kaybolması, Ötzi'nin iskeleti ile beraber iç organlarının neredeyse bir bütün olarak korunmasına ve boy, cinsiyet, yaş gibi verilerine kolaylıkla ulaşılmasına neden olmuştur. Yapılan DNA ile diğer araştırma ve ölçümlerden 1.45 metrelik iskeletin gerçek hayatta 1.60 metre boyunda, bulunduğunda $13 \mathrm{~kg}$ ağırlığında olan mumyanın gerçekte yaklaşık 50 kg ağırlığında, seyrek ama koyu renk bir saç kütlesine sahip olabileceği gibi kalıtsal hastalıklarından, yaşam sürdüğü çevrenin ekolojik düzenine kadar bir çok bulgunun derlendiği bir bütün araştırmadan elde edilen veriler, çalışma grupları tarafında kendi alanları dahilinde değerlendirilmiş ve ortaya (Resim,3) Ötzi'nin simülasyonu (etlendirmesi) çıkarılmıştır. Bu başarılı çalışmada adli-paleoantropologlar kadar kendilerini paleo-sanatçı olarak nitelendiren heykeltıraş Adrie ve Alfons Kennis kardeşlerin payı çok büyüktür.

Ötzi'nin mumyası, "1998'den bu yana Bolzano'daki Güney Tirol Arkeoloji Müzesi'nde özel olarak tasarlanmış buzul koşullarını simüle eden soğuk bir hücrede (Resim,4) sergilenmektedir. Mumya, hassas ölçeklerde $-6^{\circ} \mathrm{C}$ ve \% 99 nemli bir ortamda bulunur ve küçük bir pencereden izleyiciye sunulur. Üzerine, doğal neminin kaybolmasını önlemek için düzenli olarak steril su püskürtülmektedir" (URL-7). Böylece uygun koşullarda korunan mumya, ziyaretçilerin seyrine sunulmakta beraberinde de etlendirilmiş hali ile gerçek görüntüsüne en yakın biçimiyle izleyici ve araştırmacıların seyrine sunmaktadır. 


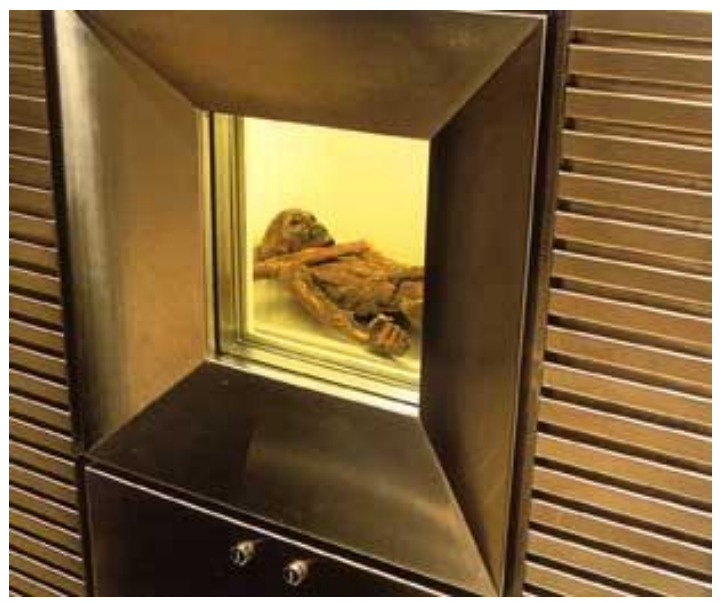

Resim 4:Soğuk Hücre, Güney Tirol Arkeoloji Müzesi, (URL-8, 2019)

Günümüz çoğu eğitim programlarında önemli bir yer içeren Müzeler, seyir alanı olmanın dışında içinde eğitim materyallerini barındıran özellikli mekanlardır. Her ne kadar toplanan materyallerin korunması, belgelenmesi ve sergilenmesi belli başlı görevleri arasında yer alsa da müzeler günümüz eğitim sisteminde önemli rol alır. "Bireylerin hem duyuşsal, hem devinişsel, hem de bilişsel yönden eğitilebilmeleri için müzelerin uygun mekanlar olduğu kabul edilmektedir" (Buyurgan ve Mercin, 2005: 61).

Her yaş ve konuya uygun eğitim programlarının yürütüldüğü müzelerde materyallerin korunması kadar sergilenme şekli de önem içermektedir.

20. yüzyılın başlarında ise sergileme fonksiyonlarına ek olarak eğitim ağırlıklı çalışmalara da yoğun bir şekilde yer verilmiştir. Atagök'ün tanımıyla bu yüzyılda müzeler toplumsal yaşam gündeminde toplum adına toplumun kültürel varlığını koruyan, eğitim kurumları konumuna gelmişlerdir....Psikologlar ve felsefeciler, duyu organları aracılığıyla alınan verilerin beyinde kodlanması ve örgütlenmesini algı olarak adlandırmaktadır. Algılama, öğrenmenin ilk aşamasıdır ve müzenin yaygın eğitim işlevinde nesnenin algılanması eğitim sürecinin birinci basamağını oluşturur. Müze sergilemesinde mekan-yapıt ilişkisi görsel algılama bağlamında oluşur ve gelişir. Sergi alanı, yapının kimliğini aktarmak ve onu ziyaretçiye gerekli algılama verileri doğrultusunda, gerekli konfor değerleri sunarken izleyici ile eserin iletişim-etkiletişimini kurmak durumundadır (Kurtay C., vd.,2003:96-97), (URL-9).

Bu noktada müze ortamının ısı, aydınlatma gibi fiziki tüm konumları ile bilgilendirme, yönlendirme gibi tüm göstergeleri ayrı bir uzmanlık alanı gerektiren durumları içermektedir. Diğer taraftan arkeolojik buluntu-nesnelerin asıllarına uygun biçimde ve kimyasına en yakın malzeme ile alan uzmanı tarafından restore edilmesi de önemlidir. Şener $(2012 ; 219)$ konuya ilişkin, "Konservasyon adıyla bilinen bu tür çalışmalar bilimsel disiplin altında yetişmiş meslek elemanlarının işidir. Bu nedenle arkeolojik alanda gerçekleştirilen her kazıda en az bir koruma meslek elemanının bulunması önemlidir." sözleriyle vurgu yapar.

Müze bağlamında, yeniden yüzlendirme de en az mimari ve restorasyon-konservasyon alanları kadar önem içermektedir. Bu gerçeklikten destekle yeniden yüzlendirme çalışmalarının bu alanda eğitim almış, alanında deneyimli disiplinlerarası çalışma grupları ile yürütülmesi gereği bir kez daha vurgulanmalıdır.

Sonuç itibariyle müzelerde sergilenen arkeolojik buluntuların (kafatası, iskelet) alıcı-izleyici tarafından gerçek biçimleri ile hayal edilmesi kolay olsa da ulaşılan sonucun çeşitliliği bilimsel araştırma ve eğitimde yanılgı payını yükseltmektedir. Bu noktada bulguların bilimsel verilerin hata payını en aza indirgeyecek araştırma ve uygulama yöntemleriyle alan uzmanları tarafından değerlendirilmesi önemlidir.

\section{Eğitim Bağlamında Yeniden Yüzlendirme Örneği}


1885 yılında ilk kez William Hiss tarafından farklı cins ve yaş gruplarına ait kadavralar üzerinden doku kalınlıkları belirlenmiştir. İlkel bir yöntem olan iğne batırma tekniği ile yaklaşık doku kalınlıkları kadavra kafası üzerinden farklı noktalardan elde edilmiştir. Üst Dudak Marjini, Alt Dudak Marjini, Çene, Dudak, Çene Altı, Mental Çıkıntı, Frontal Çıkıntı vb. 21 farklı noktadan yaklaşık doku kalınlıkları belirlenebilmektedir. Örneğin, zayıf normal ve şişman Avrupa kökenli Amerikan beyazlarına ait kadavralar üzerinden alınan yumuşak doku kalınlıkları ile Asya ve Türk toplumuna özgü yumuşak doku kalınlıkları arasında farklılıkları görmek mümkündür. Bu hassas veriler yaş ve cinsiyete göre de farklılık göstermektedir. Böylece kafatasının referansları ile tahmini veri ve bulgularla yaklaşık bir görüntüye ulaşmak olasıdır. Ortaya çıkarılan görseller adli olaylara açıklık getirirken (yaklaşık kimlik görüntüsüne ulaşılırken) diğer taraftan da müzelerde yer alan birer eğitim materyali olan kafatasları ve iskeletlerin yaklaşık görüntüleriyle sergilenmelerine ve dolayısıyla amaca uygun, içeriği sağlam ve Avrupa standartlarında bir eğitim modelinin gereğini yerine getirmeye olanak sağlamış olacaktır. Bu amaçla, 2018 yılında Gazi Üniversitesi, Heykel Anasanat Dalı lisansüstü programında uygulaması bitirilen bir tez çalışması yürütülmüştür.

Sivas ilinin Yıldızeli İlçesine bağlı Sivas'a 60 km Yıldızeli’ne 41 km uzaklıkta yer alan Kayalıpınar mevkiinde 2005 yılında Alman arkeolog Andreas Karpe ve Vuslat Muller Karpe başkanlığında başlatılan ve 2013 yılında yasal izinlerle devamı getirilen kazıda çıkarılan iskeletlerin çalışma izni Cumhuriyet Üniversitesi Antropoloji Bölüm Bakanı Prof. Dr. Ayşen Açıkkol'a verilmiştir. MÖ 1500-1400'lü yıllara ait olduğu tahmin edilen ve Hititlerden kalma harabe ören yerinde yapılan kazılar sonucunda Kayalıpınar Höyüğünde ortaya çıkan Ortaçağ dönemine ait İslam (Müslüman) mezarlığından çıkarılan kafatası (Resim,5) üzerinde Brohtwell'in çalışmalarında yararlanılarak yapılan cinsiyet tahmininde bireyin orta yaşlarda (35-45) erkek olduğu saptanmıştır.

Çıkarılan kafatası Gazi Üniversitesi Güzel Sanatlar Enstitüsü Heykel Anasanat Dalı programında Doç Dr. Aysun Altunöz tarafından yürütülen bir yüksek lisans tezinin (Abdullah Bayru, Heykel Uygulamasında Yeniden Yüzlendirme, Yüksek Lisans Tezi, Gazi Üniversitesi, Ankara) ana problemini oluşturmuştur. Tez kapsamında kullanılmak amacıyla yasal prosedürler yerine getirilerek kopyası alınan kafatası üzerinde heykel kalıp-döküm ve modelleme teknikleri kullanılarak yeniden yüzlendirmesi yapılmıştır. Yaklaşık bir yıllık araştırma ve uygulama sürecini içeren çalışmada yumuşak doku kalınlığını belirten referans noktaları kullanılmıştır. Bu çalışmada kas ve anatomi bilgisi gerektiren Rus, yumuşak doku kalınlıklarının referansları üzerine saptama yapan Amerikan methotlarının her ikisini de içeren Kombine (Manchester) metodu kullanılmıştır.

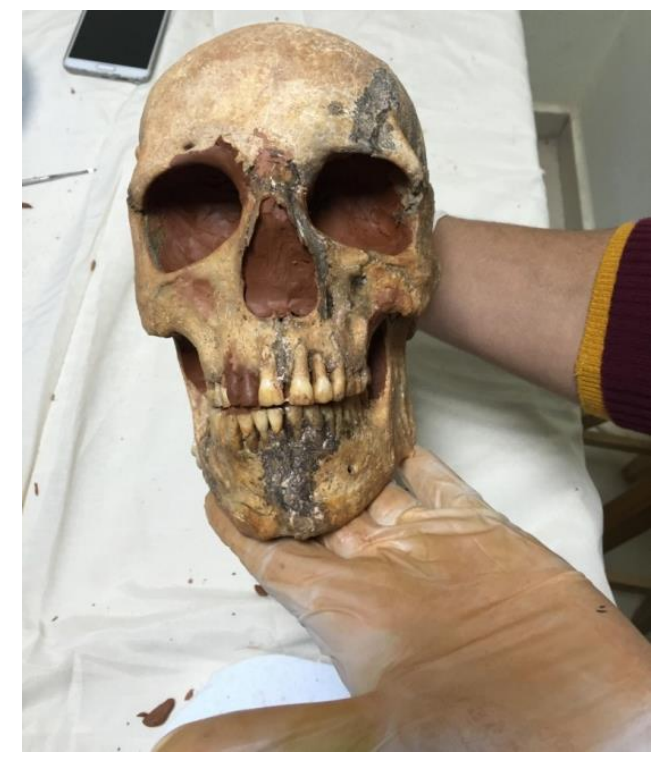

Resim 5: Kafatası, Kayalıpınar örneği, Abdullah Bayru arşivi, (URL-10, s;62, 2019) 
Kafatası üzerinde gerekli temizlik, koruma ve onarım işlemlerinin ardından $($ Resim,5) kopyasının yapım aşamasında orijinal çekirdek kafatasının kalıbı alınmıştır. Döküm tekniği kalıp içine uygulanan malzeme ile ikinci bir çekirdek kafatası elde edilmiştir. Bu kopya kafatası üzerinde farklı doku kalınlıklarını işaret eden 21 adet referans noktası belirlenmiş, beraberinde Kombine metodun gerektirdiği uygulama süreci başlatılmıştır (Resim 6,7).
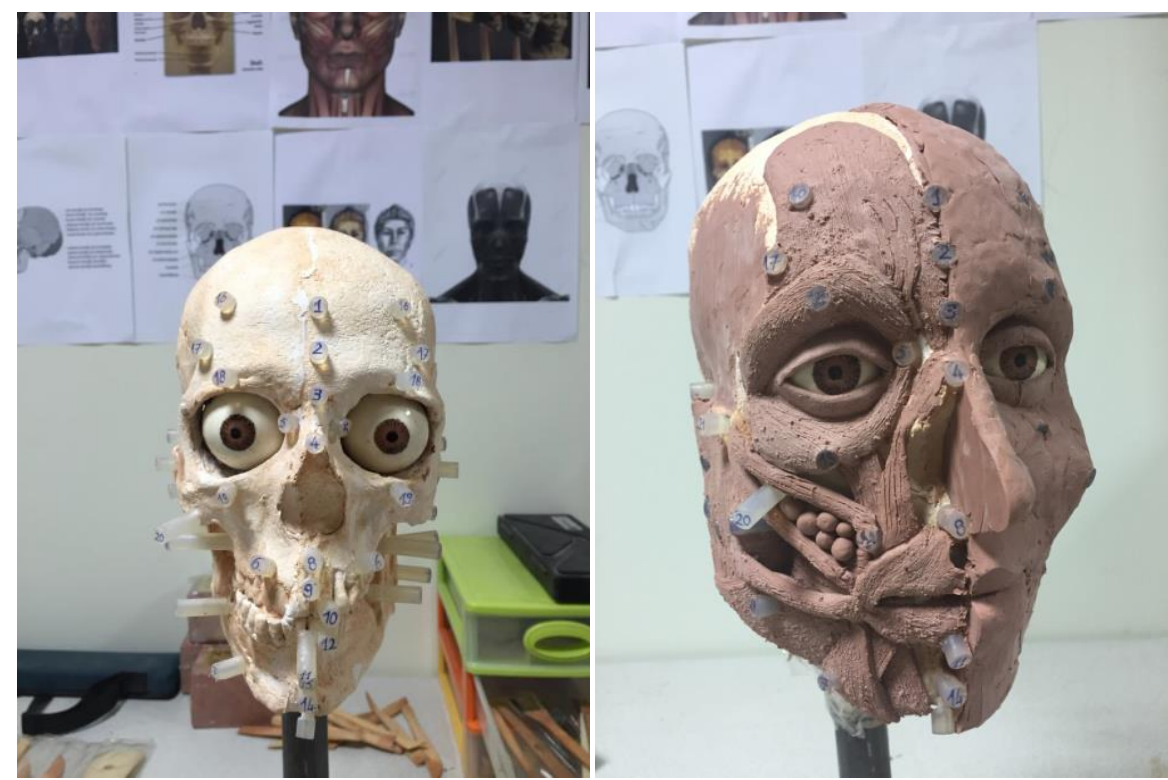

Resim 6-7: Kombine yöntem ile modelleme, Kayalıpınar örneği, Abdullah Bayru arşivi (URL$11, \mathrm{~s} ; 74-78,2019)$

Çekirdek kafatası üzerinde farklı doku kalınlıklarını işaret eden gösterge çubukları kaybedilmeden heykel modelaj teknikleri ile etüd aşaması plasterin malzeme ile titizlikle yürütülmüştür. Bu süreçte döneme, yaşına, cinsiyetine ve coğrafyasına ait insan özellikleri, dikkate alınmıştır (Resim 8, 9).
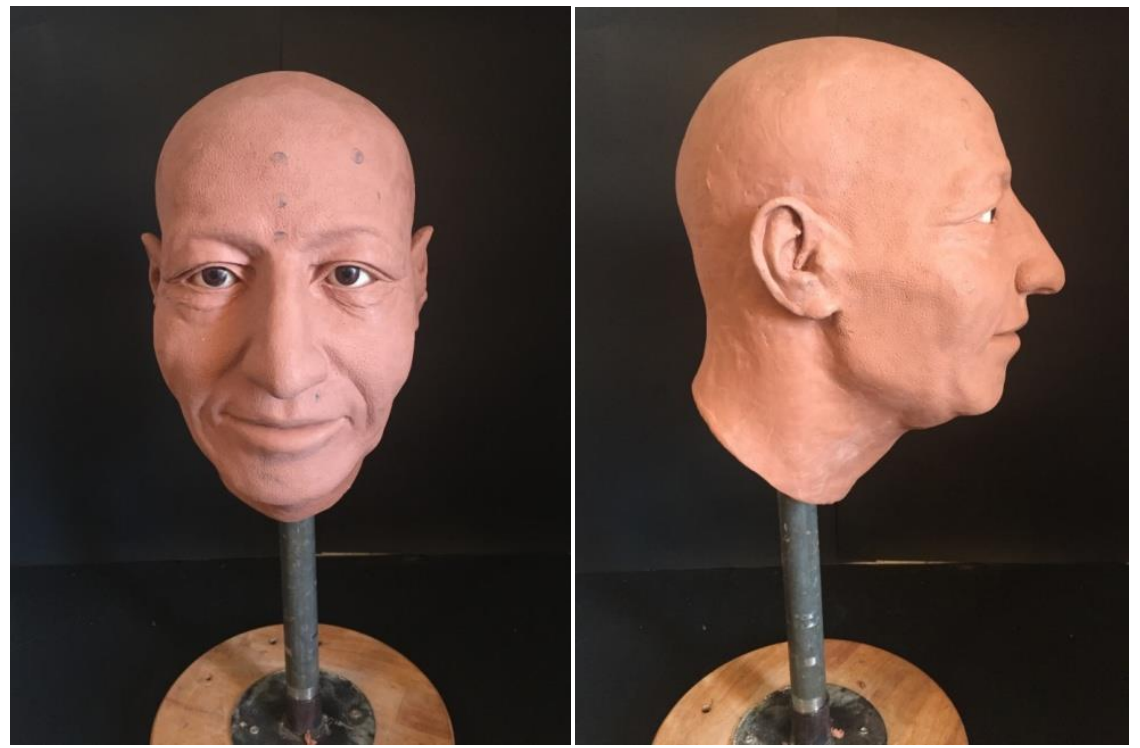

Resim 8-9: Kombine yöntem ile modelleme ön-yan, Kayalıpınar örneği, Abdullah Bayru arşivi (URL-12, s; 84, 2019)

Plasterin ile gerçekleştirilen etüd-modelaj aşaması sonlandırıldıktan sonra yüzlendirilen kafatası modeli üzerinden tekrar kalıp ve döküm işlemleri gerçekleştirilmiş, ardından 
renklendirme ve aksesuarların uygulama aşamasına (Resim 10, 11) geçilmiştir. Saç, sakal, kaş, kirpik giydirmeleri ile renklendirmenin yapılmasında yukarıda belirtilen kişilik özelliklerine vurgu yapacak tonlama ve materyallerin kullanılmasına özen gösterilmiştir.

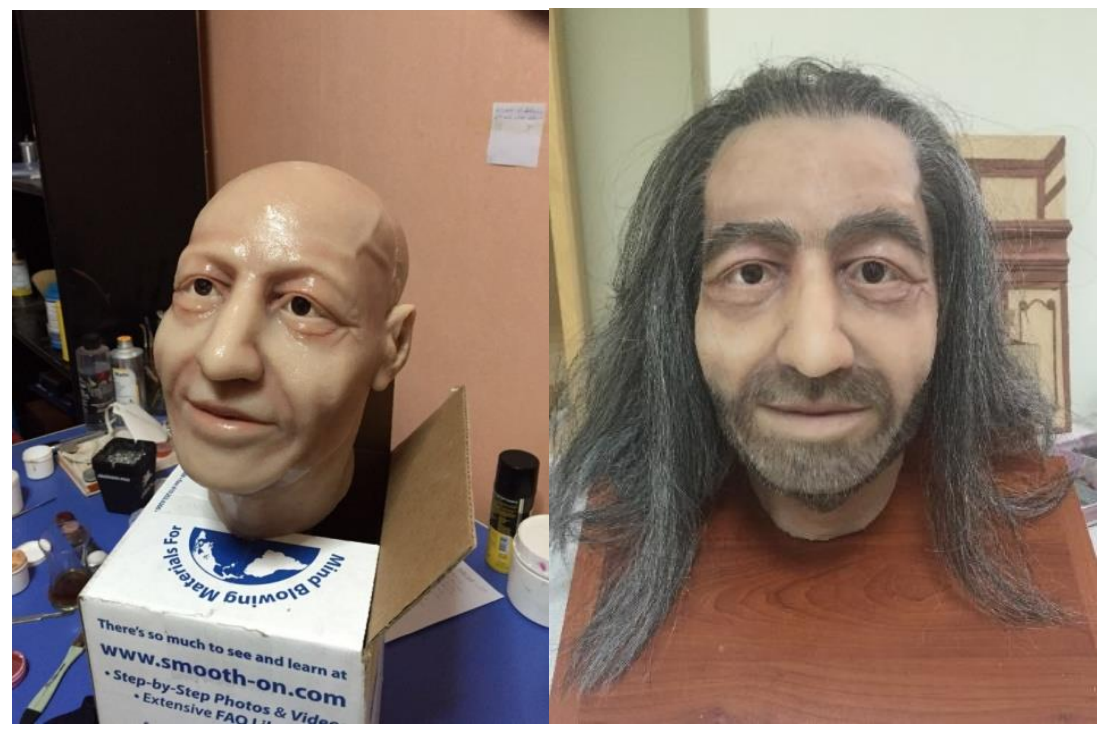

Resim 10-11: Renklendirme ve materyal ekimi, Kayalıpınar örneği, Abdullah Bayru arşivi, (URL-13, s;101-111, 2019)

Bu çalışmada amaç, heykel disiplinine farklı bir yan alan daha kazandırmak, modelaj ve döküm teknikleri ile sanatçı duyarlılığı ve el becerisini farklı bilim alanlarına destek sağlamak amacıyla örnek oluşturmaktır. Böylece disiplinler arası etkileşime somut bir örnekle vurgu yapılmış, bir kez daha adli sanatın gereğine dikkat çekilmiştir. Elde edilen sonuç konu içeriğinde yer alan farklı disiplinleri adli sanat başlığı altında toplamıştır.

\section{Sonuç}

Anlaşılacağı gibi disiplinler arası bir eğitim programını gerekli kılan ve bu amaca hizmet edecek derslerin eğitim programlarında yer alması, alan dahilinde uygulamalar ve kuramsal bilgilerin pekiştirileceği eğitim programlarının yapılandırılması ile alanda bir eksik daha giderilecektir. Bu süreçte ilgili bölümlerde yetişen uzman meslek elemanlarının alanları dahilinde diğer bilim ve araştırma ekipleriyle koordineli çalışmaları sağlanmalıdır. Anatomi bilgisinin yanı sıra el becerisi ve malzeme bilgi-deneyimi de gerektiren bu çalışmalar günümüzde müzelerde ve adli bilimlerin birçok alanında yoğun ihtiyaç dahilinde sıkça başvurulmaktadır. Gelişen teknoloji ve kimya sanayii ile kullanılan malzeme ve materyallerin çeşitliliği alanda üretilen örneklerin kalitesini artırdığı gibi kuramsal ve uygulama pratikleri beraberinde uzman meslek gruplarını da gerekli kılmıştır.

Adli sanatın artistik beceri ve bilimsel bilgiyi bir araya getiren ve uygulama alanının özel bir eğitimi gerektirdiği kabul edilen bir gerçektir (NPIA ACPO, 2009 pg:7) (URL-14). Ülkemizde sanat eğitimi veren yükseköğretim kurumlarında bu güne dek resmi ya da gayri resmi olarak adli sanat ve adli heykeltıraşlık eğitimi verilmemiş, bu kapsamda eğitim veren bir uygulama merkezi de kurulmamıştır. Bu konuda eğitim kurumlarına önemli görev düşmektedir. Yeniden yüzlendirme alanında yetkin eleman ve uzman kadronun eğitim ve öğretiminin üniversiteler ve enstitüler bünyesinde yer alan kurum ve kuruluşlar tarafından özenle yürütülmesi kaçınılmaz bir gerekliliktir. Unutulmamalıdır ki adli heykeltıraş eğitimi plastik sanat eğitiminin tüm prensip ve tekniklerini kapsamasına karşın bu amaç için özenle hazırlanmış eğitim programını içermelidir. Bu kurumlarda adli sanat programlarının açılması ve desteklenmesi, beraberinde adli heykeltıraşların yetiştirilmesi ile heykel sanatı kendi alanını genişletirken diğer bilim dallarına da katkı sağlayacaktır. 


\section{KAYNAKÇA}

Buyurgan, S. ve Mercin, L. (2005). "Görsel Sanatlar Egitiminde Müze Egitimi ve Uygulamaları",(Editör: Vedat Özsoy). Ankara: Varan Yayıncılık.

Şener Y.Selçuk, (2012). "Arkeolojik Alanda In situ (Yerinde) Mozaik Koruma Yöntemleri", JMR (Uludağ Üniversity Journal Of Mosaic Research) Vol:5, 201-220, sayfa 219, Ege yayınları, Paragraf Basın Yayın AŞ, İstanbul, ISSN:1309-047X

Taylor, K. T. (2001). Forensic Art andIllustratıon. NY Washington D.C:CRC Press. ISBN: 08493-8118-5

URL-1, (2019). "An Introduction to Facial Reconstruction" Balkan Journal of Stomatology, Vol.11, s:76, ISSN: $1107-1141$ https://pdfs.semanticscholar.org/72db/edfe46af3ff1016c9f40d090e793eaf1b53f.pdf (Erişim Tarihi:01-12-2019), (In English).

URL-2, (2019). "Reconstructing Kıng Midas: A First Report", Anatolian Studies, (1989), Vol. 39 sayfa 159-165, British Institute, Ankara, DOI: 10.2307/3642820 https://www.jstor.org/stable/3642820?seq=4\#page_thumbnails_tab_contents (Erişim Tarihi:01-12-2019), (In English).

URL-3， (2019), https://www.rn-ds-partnership.com/reconstruction/midas.html, (Erişim Tarihi: 07-11-2019), (In English).

URL-4， (2019). http://www.hurriyetdailynews.com/wrong-gobeklitepe-skulls-reported-inturkish-media-116670 (Erişim Tarihi:07-11-2019) (In English).

URL5,(2019).https://www.academia.edu/36453686/The_Face_of_Gordion_with_Ears_of_Kin g_Midas (Erişim Tarihi:07-11-2019) (In English).

(URL-6), (2018). http://www.iceman.it/wp-content/uploads/2016/08/museo_4.jpg (Erişim Tarihi: 21-09-2018) (2018)

URL-7, (2018). http://www.iceman.it/en/the-mummy/), (Erişim Tarihi: 22-09-2018), (In English).

(URL-8), (2019). http://www.clinicalgaitanalysis.com/art/footwear.html, (Erişim Tarihi: 2305-2019)

URL-9, (2018). Kurtay,C., AYBAR, U., BAŞKAYA, A., AKSULU, I.(2003). Gazi Üniv. Müh. Mim. Fak. Dergisi 18 (2): 95-113.

URL-10， (2019). https://tez.yok.gov.tr/UlusalTezMerkezi/tezSorguSonucYeni.jsp (Erişim Tarihi:07-11-2019)

URL-11， (2019). https://tez.yok.gov.tr/UlusalTezMerkezi/tezSorguSonucYeni.jsp (Erişim Tarihi:07-11-2019)

URL-12 (2019). https://tez.yok.gov.tr/UlusalTezMerkezi/tezSorguSonucYeni.jsp (Erişim Tarihi:07-11-2019) 
URL-13， (2019). https://tez.yok.gov.tr/UlusalTezMerkezi/tezSorguSonucYeni.jsp (Erişim

Tarihi: 07-11-2019)

URL-14, (2019). NPIA ACPO, (2009): http://library.college.police.uk/docs/acpo/facialidentification-guidance-2009.pdf ,23-05-2019 (In English)

\section{EXTENDED ABSTRACT}

The subject studied under Interdisciplinary Interaction: Forensic Art and Facial Reconstruction within the context of Musuem indicates new work disciplines generated from different disciplines pieced together. Besides its conribution to both art and scientific area, the necessity of forensic art under the roof of forensic sciences is emphasized. The standing and importance of facial reconstruction studies in forensic art and musuem-musuem education is explained with examples while analysis of examples from the literature are stated with comparisons.

In this day and age, the hybrid study fields of collective studies established as interdisciplinary in scientific and academic studies will imply the existence of expert professionalists in the field. To provide training for these fields of professions, support for theoretical and application oriented programmes in educational institutions will be supplied. In this sense, within this article, the importance of forensic art which makes interdisciplinary studies essential is evidently emphasized.

The objective of the article, where the contribution of Forensic art study scopes to musuem and forensic sciences besides educational field is verified with concrete application example, is to emphasize the necessity of including facial construction study in postgraduate education programmes and draw attention to the joint study scope of science and art with the support generated from their own disciplines.

For this purpose, a successful facial reconstruction study has been carried out on the skull which has been brought to light with the excavation started in 2005 located in Kayalıpınar, Yıldızeli in Sivas province and given Prof. Dr. Ayşen Açıkkol from Cumhuriyet University and Department of Antropology the authorization to study on. The facial construction which forms the core of the postgraduate study performed by Abdullah Bayru with the supervisorship of Ass. Prof. Dr. Aysun Altunöz, is implemented with combined method. In conclusion, the study brought out has on one hand generated a hybrid study scope where interdisciplinary coordination helps science and art meet at a common goal and on the other hand makes a major contribution to musuem and musuem education.

Today, the education applications in musuems constitute an important part of the education. Archeological and ethnographic exhibition materials, which each can be used as educational materials, constitute an important place in modern-day musuem education models. At this point, these materials are to be qualified and adequate exactly to serve the needs of education and training. The exhibitings of the skeletons in the musuems with facial reconstruction will improve the quality of the musuem and musuem education programmes. Hence, new study fields like forensic art or facial reconstruction generated with the coordination of art and science will be necessary. A lot fall to the educational institutions on training expert art professionalists. First of all, moral and material promotion will be needed for postgraduate programmes generated with hybrid science-art fields like forensic art, facial reconstruction, etc in universities' postgraduate programmes.

Virtually as an educational material, with creating simulative displays of the skeletons exhibited in the archeological musuems in our country which have the quality and variety above European standarts, the exhibition quality will improve; alongside forensic units, police, forensic sciences, forensic anthropology, forensic sociology and so forth all related fields will span their boundaries and make significant contribution to all science, art and social activities. 